Jeffries Vincent

Northridge

\title{
LOVE IN MARITAL AND FAMILY RELATIONSHIPS: MEANINGFUL STRUCTURES AND INTERACTION PROCESSES ${ }^{*}$
}

\begin{abstract}
Citation: Jeffries V. [Love in marital and family relationships: meaningful structures and interaction processes] // Nasledie [Heritage]. 2020, No. 2 (17). - pp.74-95.

DOI: https://doi.org/10.31119/hrtg.2020.2.5

This study examines the meaningful structure and social interaction patterns associated with love. Both marital and young adult-parent relationships are studied and compared. The history of ideas about the nature of love indicates two basic dimensions: the intent to benefit another, and the need for interpersonal association. In this study they are described as benevolence and attraction, respectively. Questionnaire data from two separate samples provides for examining this duality of love in interaction in three interpersonal relationships: between spouses, and between young adults and their mothers and their fathers. Both self-reported love, the love that is given to the other, and perceived love, the love that is viewed as received from the other, are measured. Factor analysis shows that benevolence and attraction are separate dimensions of love in both self-reported and perceived love in both marital and young adult-parent relationships. Whether receiving love from another is associated with giving love in return is examined. Regression analysis shows that perceived attraction generally explains more variance in self-reported love than does perceived benevolence. However, benevolence usually maintains significant independent effects.
\end{abstract}

Key words: interaction, meaningful, love, benevolence, attraction, sentiment.

Джеффрис В. Любовь в супружеских и семейных отношениях: структуры значения и процессы взаимодействия

Данное исследование рассматривает структуры значения и модели социального взаимодействия, связанные с любовью. Изучаются и сравниваются как брачные, так и отношения между молодыми родителями. История представлений о природе любви указывает на два основных измерения: намерение принести пользу другому и необходимость межличностной ассоичиации. В этом исследовании они описываются как соответственно доброжелательность и

\footnotetext{
* This research was supported by a grant from the Institute for Research on Unlimited Love, as part of the Fetzer Institute's initiative on Scientific Research on Altruistic and Compassionate Love. Earlier versions of this article were presented at the Annual Meeting of the Pacific Sociological Association in Oakland, California, March 29 to April 1, 2007 and at the American Sociological Association Annual Meeting in Boston, Massachusetts, August 1-4 2008. Thanks are due to Helen Dosik, Cecelia Jeffries, Bradley McAuliff, Lawrence T. Nichols, Edward Ransford, and Jerald Schutte for helpful comments on earlier versions of this article. 
притяжение. Данные анкет двух разных выборок предусматривают изучение этой двойственности любви во взаимодействии трех видов межличностных отношений: между супругами, между молодыми взросльми, а также их матерями и отцами. Оба измерения выявили любовь, любовь, отданную другому, и вытекающее из нее чувство любви, любовь, которая рассматривается как полученная от другого. Факторный анализ показывает, что доброжелательность и притяжение являются разными измерениями любви как по самооценке, так и по ее восприятию как в супружеских отношениях, так и в отношениях между молодыми родителями. Исследуется следующая проблематика связано ли получение любви от другого с отдачей любви взамен. Регрессионный анализ показывает, что воспринимаемое притяжение обычно объясняет больиую вариативность в самооиенке любви, чем воспринимаемая доброжелательность. Однако доброжелательность обычно содержит значительные независимые влияния.

Ключевые слова: взаимодействие, осмысленность, любовь, доброжелательность, притяжение, чувство.

\section{LOVE IN MARITAL AND FAMILY RELATIONSHIPS: MEANINGFUL STRUCTURES AND INTERACTION PROCESSES}

Love is a powerful force in the lives of individuals, in social institutions, and in the general culture. Love increases vitality and longevity, subdues aggression and enmity, is an integrative and creative power in the lives of individuals, gives rise to love in others, is a vital force in human relationships, and enhances goodness, freedom, and happiness in the social order [Sorokin, 2002:47-79].

Love has various aspects [Sorokin, 2002:3-14]. Ontologically, love, along with truth and beauty, «is one of the highest forms of a unifying, integrating, harmonizing, creative energy or power» [Sorokin, 2002:6]. Across the world religions, love has two main aspects, love as Eros and love as Agape. In their highest forms, Eros is centered on the development of the positive and ethical aspects of the self, while Agape is centered on freely giving benefit to all others. Ethically, love is inseparable from truth and beauty, and is viewed as the essence of goodness. Psychologically, love entails an identification and a merging of one individual with another. Its nature is thus altruistic. It is a «lifegiving» force that entails both freedom and power. On the social level of analysis, love is a «meaningful interaction - or relationship - between two or more persons « in which «the aspirations and aims of one person are shared and helped in their realization by other persons» [Sorokin, 2002:13].

Meaningful social interaction is the most generic sociological phenomenon. It is generic in the sense that it is an inherent and basic property and process of human behavior and of the sociocultural reality. Any particular process of interaction entails thinking and acting human beings, the meanings, values, and norms involved in their interaction, and the overt actions and material vehicles that objectify them [Sorokin, 1969:39-42].

Love is a bond between two or more individuals that is manifested in meaningful social interaction. Because love both motivates and unites individuals, it is a direct or indirect factor in shaping a significant amount of the meaningful interaction that takes place in 
society. Continuing interaction between members of a family is the primary social context in which love is most likely to be manifested with intensity and with long duration [Turner, 1970; Zimmerman, 1947].

In this study, love as a process of social interaction is examined in its two fundamental dimensions: seeking to realize the good of the other, and receiving the gratification of basic human needs of close interpersonal interaction and association. Their dimensions are identified as the love of benevolence and the love of attraction, respectively. Two separate samples provide questionnaire data pertaining to love between married persons, and love between young adults and both their mothers and their fathers. In the analysis of these three social relationships both self reported love, that viewed as given to the other, and perceived love, that viewed as received from the other, are measured, for both benevolent and attractive love. This comparative research design provides for a pioneering investigation of love in two of the most fundamental kinship relationships, those between husbands and wives, and those between parents and their adult children.

The study explores two basic research questions, the first dealing with the structure of love, the second with the dynamics of love: (1) What are the similarities and differences between the meaningful structure of love in marital relations and in young adult-parent relationships? (2) In the dynamics of interpersonal interaction, what influence does the perception of receiving love from a person have on giving love to that person in return?

\section{PROPERTIES OF LOVE: REVIEW OF THE LITERATURE}

Overviews of the history of ideas about the nature of love indicate that love can be regarded as a duality. Its two basic dimensions are the giving and the receiving aspects of love [D'Arcy, 1960; Nygren, 1969]. For example, in his extensive analysis of ideas about love from early thought to the modern era, Singer [Singer, 1984a; Singer, 1984b; Singer, 1987] maintains that views of love have clustered around two basic forms: bestowal and appraisal. Bestowal derives from the capacity to love and centers on the welfare of the other. Appraisal derives from self-gratification and is utilitarian.

Classic renditions of this duality are Aristotle's [Aristotle, 1941: 1058-1076] true friendship contrasted with friendship for profit or pleasure, and Aquinas's [Aquinas, 1981:703-716,1263-1317] love of benevolence contrasted with love of desire. In contemporary social science this twofold nature of love is expressed in distinctions such as Rubin's [Rubin, 1973] caring and needing love, Shibutani's [Shibutani, 1961:343-346] disinterested and possessive love, and Maslow's [Maslow, 1968:42-43] unselfish «B» love and needing «D» love. Most recently, compassionate love, which is focused on the good of the other, is compared to romantic love, which derives primarily from self-interest [Underwood, 2009:3-5; Neff and Karney 2009:201-202].

Despite differences in conceptualization and terminology, this same dualism is evident in research studies that have attempted to identify different components of love based on data of some sort, usually quantitative. The distinction between the giving/bestowal and receiving/appraisal components of love, respectively, can be seen in varying degrees in the following: Swensen's [Swensen, 1972] tolerance, non-material and material evidence of 
love, and expressions of affection, contrasted with feelings and self-disclosure; Clark and Mills [Clark, Mills, 1979] communal relationship contrasted with exchange relationship; Davis and Todd's [Davis, Todd 1982] care and the acceptance/tolerance component of viability, contrasted with intimacy, passion, and the trust and respect components of viability; Steck, Levitan, McLane, and Kelley's [Steck, Levitan, McLane, Kelley, 1982] care, contrasted with need conceptions of love; Tennov's [Tennov, 1984] affectional bonding, contrasted with limerence; Hendrick and Hendrick's [Hendrick, Hendrick, 1986] agape and to a lesser extent storge, contrasted with pragma, eros, mania, and ludus; Sternberg's [Sternberg, 1986] commitment to maintain love, contrasted with passion and intimacy; Saver, Hazen, and Bradshaw's [Saver, Hazen, Bradshaw, 1988] care-giving, contrasted with attachment and sexuality; Fehr's [Fehr, 1988] commitment, contrasted with love; Jeffries [Jeffries, 1993] virtue contrasted with attraction; Swidler's [Swidler, 2001] prosaic-realistic, contrasted with mythic cultures of love; Collins and Ford's [Collins, Ford, 2010] care-giving contrasted with attachment (care-seeking).

In this study the giving/bestowal dimension of love is considered as benevolence, the receiving/appraisal dimension as attraction. Each of these two general dimensions of love derives from different motivations. Each dimension is manifested in varied components that express the basic orientation of that love in differing and more specific manners.

\section{NATURE OF LOVE}

\section{Love as Benevolence}

The essence of benevolent love and its motivational source is the intent to do good to the other, whether person or group, in some manner [Aristotle, 1941:1058 1102; Aquinas, 1981:1263]. This intent is manifested in various ways in interaction with others in a great variety of social situations.

In contemporary social science this dimension of love is often identified as altruistic love [Jeffries, 1998], and most recently, compassionate love [Feher, Sprecher, Underwood, 2009]. Since this love is centered on the welfare of the other, it often entails some degree of sacrifice of self. There are a variety of ways in which individuals can «give of themselves for the good of another» [Perlman and Aragon, 2009:438]. Several research studies indicate that willingness to sacrifice for the partner is positively related to relationship satisfaction among couples [Johnson, Hornne, Neyer, 2018:637].

The concept of virtue provides a basic framework for elaborating on the nature of benevolent love, and thus the varied underlying dispositions involved in giving benefit to others. An extensive and systematic analysis of philosophical and religious traditions shows that virtue is a central idea in a tradition of thought that ranges from classical Greece to the contemporary era [Peterson, Seligman, 2004:28]. In this tradition the virtues are regarded as representing moral goodness and the greater perfection of human nature [Fowers, 2005; MacIntyre, 1984; Pieper, 1966; Smith, 2010:384-433].

The virtues are attitudes and behavior patterns that can become good habits through repetition. Both Levine [Levine, 1995] and Smith [Smith, 2010] have considered how the Aristotelian tradition of virtue morality, including its ideas regarding society and the good, 
can contribute to current sociological perspectives. Since the mid 1990s a considerable body of theoretical and research literature focusing on the virtues has developed within psychology [Lopez, Snyder, 2003; Peterson, Seligman, 2004].

The intent to benefit the other that is the essence of benevolent love can be specified by the concept of virtue. Five virtues from Aquinas's [Aquinas, 1981: 817 894, 1263 1879] scheme of the virtues serve to identify particular ways in which one individual can seek to benefit another. The fundamental characteristic of seeking to benefit another can be expressed in a particular way in the manifestation of each virtue: (1) Temperance involves moderation and discipline of the appetites and passions; (2) Fortitude indicates the willingness to undergo difficulties, hardships, and dangers for the welfare of another; (3) Justice is giving what is due to another in terms of some standard of fairness; (4) Charity is benefiting another in such ways as helping, forgiving, and meeting needs; (5) Prudence is the use of reason in seeking to know what is good, and in choosing the appropriate means to realize it. This virtue is the rational and deliberative component of benevolent love. In marriage and family, the exercise of prudence involves using deliberation to decide the most appropriate means to benefit a spouse or family member.

Benevolent love composed of these virtues can be regarded as a moral system that influences thought and behavior in both marital and family interaction. In the terms of general public usage, benevolent love as virtue can be divided into five components: selfcontrol, steadfastness, fairness, kindness, and reason applied toward realizing means and ends that are good. Which virtue is most suitable for benefiting the other varies according to the nature of the situation [Jeffries, 1998]. Seeking to do good to the other in most instances involves the manifestation of one or more of the virtues.

\section{Love as Attraction}

Basic human needs and desires for close interpersonal association with another person are the primary motivating force underlying attractive love. Their gratification gives impetus to positive attitudes toward the other person. The continuance of this form of love depends to some degree on their satisfaction.

The components of attractive love were formulated primarily from the writings of Turner [Turner, 1970:216 245]. Each of the five components of love as attraction manifests the characteristic of receiving gratification in a particular manner from association with another person: (1) Admiration is a positive evaluation of the other person. It provides gratification by enhancing self conception through identification with the other; (2) Companionship is gratification deriving from being with the other and doing things with them; (3) Trust is the belief that one can rely on the other. It satisfies needs, such as those for security and predictability; (4) Intimacy is sharing of the private and personal. It fulfills needs such as those for sharing and for disclosure; (5) Emotional closeness is positive emotional bonding. It gratifies through alleviating loneliness and providing a sense of union with another person.

The Reality of Love in Personality and Social Interaction

Love deriving from the intent to benefit, and love deriving from the satisfaction of basic human needs, conceptualized as benevolence and attraction, respectfully, are analytically 
separable. However, both of these dimensions of love are characteristically related to each other, and are implicated at two levels of analysis: personality, in terms of individual motivation and behavior, and social, in terms of continuing episodes of social interaction. At both levels of analysis, love can vary in its configuration, defined as the relative balance between benevolence and attraction, and the degree of manifestation of the components of each dimension. In the general configuration of the love a given individual has for another, both dimensions of love are almost inevitably operative, though they may vary considerably in influence and overt manifestation [Rubin, 1973:214; Singer, 1987:389406; Sorokin, 2002:3-6].

\section{Previous Research}

Three previous research studies [Jeffries, 1988; Jeffries, 1990; Jeffries, 1993] have uniformly indicated that benevolence as virtue and as attraction are two statistically separate factors in the young adult-parent relationship. A previous study has shown that benevolent love as virtue is positively related to marital solidarity [Jeffries, 2006; Jeffries, 2014], while three studies have shown virtue to be positively related to solidarity in the young adult-parent relationship [Jeffries 1987; Jeffries, 1988; Jeffries, 1990]. Two studies [Jeffries, 1988; Jeffries, 1990] have also shown that attractive love is positively related to solidarity in the young adult-parent relationship. In these studies, solidarity was measured in terms of happiness and satisfaction relative to the relationship.

This study employs questionnaire data to further extend the analysis of love in interpersonal relationships. The structure of love in both marital and young adult-parent relationships is presented and compared. The association between receiving and giving love in both these relationships is also analyzed, thus further extending the analysis of the dimensions of love.

\section{THE STRUCTURE OF LOVE: MEANINGS AND SENTIMENTS}

Love is a meaningful structure that is manifested in social interaction. Love influences social interaction, and in turn is influenced by the content of interaction. The concept of schema provides a perspective for understanding the two dimensional structure of love and its place in personality and in social interaction. Cognitive theory posits the existence of psychic structures, called schemas, which are basic elements in the mental life of every individual [Brewer, Nakamura, 1984; Markus, Zajonc 1985:142-174; Moskowitz, 2005:153-192]. The mind contains countless schemas that give meaning to a vast number of objects, ideas, persons, and social situations. Stored in memory at both conscious and unconscious levels, schemas can be activated by internal psychic sources or social situations and cultural expectations. When they are activated, schemas become the elements of consciousness that define reality and directly influence behavior in social interaction, both in general ways and in particular social situations.

Schemas are identified and distinguished by their meaningful content. Different schemas are integrated in varying degrees of affinity with other schemas. In one form of integration 
abstract schemas contain one or more levels of more specific schemas that pertain to the same meaningful domain. This hierarchical model of embedding appears to characterize the love schema. A general idea of the meaning and practice of love is the foundational schema. Embedded within this are the two schemas of benevolence and attraction, entailing benefiting another and fulfilling one's needs, respectively. This is the second hierarchical level composed of the two basic dimensions of love. These schemas derive from the fundamental nature of interpersonal relationships, which inevitably involve orientations of both giving and receiving. The components of benevolence and attraction are embedded subschemas that specify each of these more generalized dimensions regarding the meaning and practice of love. In the case of benevolent love, the components are the virtues of temperance, fortitude, justice, prudence, and charity. In the case of attractive love, the components are admiration, companionship, trust, intimacy, and emotional closeness. These components of benevolence and attraction, respectively, constitute the third and most specific level of the basic and foundational love schema.

Another form of relationship between schemas is one in which schemas pertain to different meaningful domains, but are integrated with other external schemas to some degree because of their meaningful content and the nature of social life. Thus role schemas such as gender or age, and relational schemas, such as spousal or parent-child, are implicated in schemas pertaining to social interaction and relationships with others. These schemas find their source in prevailing cultural norms and expectations regarding positions and social relationships, respectively [Moskowitz, 2005:161-162]. They are particularized in the role-making of interpersonal interaction between individuals [Turner, 1962]. These role and relationship schemas shape both the input to, and the output from, the love schema as its content is manifested in the consciousness and behavior of the individual in the process of interaction in particular relationships.

The schematic structures of love are most commonly activated in the context of past, present, or anticipated interaction with other specific individuals. At this level of specificity the abstract love schemas and their subschemas are particularized in relation to a given individual. In this love for a specific individual an additional cognitive structure, the sentiment, becomes pivotal in the manifestation of the love schemas in attitudes and behavior. Sentiments can be considered the primary operational cognitive structure in social interaction in interpersonal relationships [Shibutani, 1961:322-366; Turner, 1970:224228]. A sentiment is a relatively organized structure of attitudes toward a particular person [Shibutani, 1961:332]. Sentiments involve perception, evaluation, emotions, and a pattern of response. The sentiment of love one person has for another is a particularized meaningful complex composed of a given level and configuration of the components of both benevolence and attraction.

A basic research question to be explored in the data is whether the distinction between benevolent and attractive love can be maintained despite the differing role and relational schemas involved in marital and family relationships and in gender and generational cultural expectations. If these dimensions of love remain distinct across these variations, this suggests both the importance and the independent effects of the meaningful structure of love schemas in interaction and in interpersonal relationships. 


\section{THE DYNAMICS OF LOVE: SENTIMENTS AND INTERACTION}

A theoretical basis for interpreting the manifestation of sentiments in ongoing interpersonal relationships is provided by symbolic interactionism [Blumer, 1969: 1-6; Shibutani, 1961; Stryker, Statham, 1985; Thomas, 1966]. From this theoretical perspective the manner in which the interacting parties define themselves, the other, the social relationship, and its cultural expectations are an important source of behavior. The content of behavior is important in this construction of meaning. Also relevant is the behavior of the self, which reacts back on consciousness and shapes meaning [Archer, 2000]. An important factor in this construction of meaning is the capacity of individuals to deliberate and act as causal agents in defining and directing their own behavior. Turner [Turner, 1970] has applied these foundational ideas of interactionism to the study of marital and family relationships.

Structures of meaning about the nature of love and role and relational expectations influence the ongoing interaction in marriage and family. Sentiments particularize these general cultural expectations in relation to a given individual, such as a spouse or parent. In long-term relationships such as marriage and family, relatively stable meanings and corresponding behaviors regarding the manner and degree of the expression of love between the parties typically evolve and are regularly expressed in interaction. Under such conditions the manifestation of given components of love can become habitual, and often subconscious.

This general perspective forms the basis for analyzing the sentiment of love in an interactional context. W.I. Thomas's (1966) formulation of situational analysis interprets the interactional process with three basic elements: the objective conditions of the situation, the pre-existing attitudes of the individual, and the definition of the situation. This definition represents the individual's selection, interpretation, and ordering of elements of the objective situation [Thomas, Znaniecki, 1958:68]. Central in this analytical framework is the idea of the "definition of the situation,» prominently referred to as the Thomas Theorem [Merton, 1968:475-478; See also Coser, 1977:520-521]. This theorem states that the meaning individuals ascribe to situations is a prime determinant of how they will respond to them, and therefore of the consequences that result [Thomas, Thomas, 1928:572; Thomas, 1966:160].

In this study, the Thomas Theorem interprets the analysis of whether the perception of receiving love from another is associated with the manifestation of love toward that person. The dynamics of both benevolent and attractive love are presented and are compared. Examined in the aggregate of the sample, perceived love is the definition of the situation. Self reported love is the consequence.

\section{METHODOLOGY}

$\mathrm{S}$ a m p le s

This study is based on survey data from two separate samples. These are a sample of married individuals, identified as the «marriage» sample, and a sample of university 
students, identified as the «family» sample. The author of this article gathered the data for both samples.

The marriage sample consists of 103 individuals, including 47 married couples. All of the respondents have been married 25 years or more. Fifty-one percent are male, 49 percent female. The mean age is 64 , the median 63 , the mode 60 , with a range of 44 to 90 . The sample, selected by referral, consists of individuals who, for the most part, attend religious services regularly. In many instances, they are also active in their congregations. Subjects were affiliated with 9 different religious denominations, including 2 branches of Judaism, Roman Catholicism, and 6 Christian denominations.

The family sample was collected over a period of four years from 731 students in 18 lower division introductory sociology courses at a large urban general-purpose university. Classes in introductory sociology are an option in the general education requirement, and include students of diverse majors. As a result, the data show that the sample does not contain a disproportionate number of students majoring in sociology. Sixty percent of the sample are female, 40 percent male. Seventy-eight percent are under age 21, and 92 percent are under age 25. Mean age is 20.2, median and mode are both age 19. Seventy percent lived with both parents until they finished high school. Conversely, six percent (44) of subjects did not answer the questionnaire for the male parent. Overall, the interaction with parents being studied is thus ongoing or recent for a high proportion of the respondents in the sample.

\section{Me as ures}

For both the marriage and family samples, love was measured using a previously validated scale of benevolence and attraction [Jeffries, 1993]. Two manifestations of love were measured: (1) «self-reported» love, the respondents' view of his or her love given to the other; (2) «perceived» love, the respondents' view of the love received from the other. They were measured in both samples using the following probes, with appropriate changes in pronouns: In your relationship with your (spouse) (female parent) (male parent), when the opportunity occurred to do so, how often did (you) (they) do each of the following. A five point numbered scale ranging from «Never» to «Always» was provided for responses to items that followed the probe.

Items measuring self-reported love and perceived love are the same, except for appropriate changes in wording. The following five items measured the five virtues of benevolent love: Temperance: Practiced self-discipline for the good of your (their) relationship with them (you); Fortitude: Been ready to endure hardships for their (your) happiness; Justice: Did your (their) best to fulfill your (their) responsibilities to them (you); Charity: Been helpful to them (you); Prudence: (Showed they had) Thought over how you (they) could contribute to their (your) well-being. The following five items measured the five components of love as attraction: Admiration: Admired them (you); Companionship: Liked being with them (you); Trust: Trusted them (you); Intimacy: Confided in them (you); Emotional closeness: Felt close to them (you) emotionally.

Only the above items were used in the marriage sample. In the family sample, the complete scale of 20 items, consisting of the above 10 items and an additional item for each component, was used. This complete scale is presented in the validation study [Jeffries, 1993]. In the marriage sample responses to the benevolence and attraction measures were 
gathered for the early, middle, and recent years of marriage. Summary scores for the full span of the marriage were constructed from this source. This procedure provides a general assessment for each marriage, while maximizing the range of a somewhat skewed distribution. To facilitate comparison of marital and family love, the same form of summary scores was used for the data from the family sample. In this instance scores were computed based on the complete 20 -item scale.

Reliability, measured by alpha, for the marriage sample is .81 and .88 for the benevolence scales, .86 and .88 for the attraction scales, and .88 and .93 for the total indexes, for selfreported and perceived love, respectively. For the family sample for female and for male parents, measured separately, benevolence scales range from .87 to .92 , attraction scales range from .90 to .92 , and the total index for love from .92 to .94 . Both self-reported and perceived loves are included in these results for the family sample.

\section{RESULTS: THE MEANINGFUL STRUCTURE OF LOVE}

Basic findings. Table 1 presents descriptive statistics and two-tailed paired samples t-tests comparing benevolence and attraction in marriage and in young adult-parent relationships. Two general findings are noteworthy.

First, in both samples, the scores exhibit sufficient variation from low to high to fulfill expectations in regard to the sentiment of love and its measurement. The possible range of scores for the marriage sample is 15 to 75, for the family sample 10 to 50. Minimum and maximum scale values show that the marriage sample is skewed to the high end of the scale. This undoubtedly reflects, to some degree, that the sample consists of individuals in marriages of 25 years or more. The family sample shows a wide range of scores, in all but one instance including the maximum range possible.

Second, there are differences in the incidences of the manifestation of the two dimensions of love in each of the samples. In the marriage sample, subjects report a significantly $(<.001)$ higher incidence of self-reported attraction than benevolence. A similar ordering of the dimensions occurs with perceived love, though the difference between attraction and benevolence is minute (.04) and nonsignificant. This finding contrasts with the family sample. Here the means for benevolence are uniformly higher than for attraction, whether self-reported or perceived love is the subject. Three of the four comparisons are statistically significant $(<.001)$.

These findings indicate that benevolence has a more central role in family interaction than attraction. Attraction appears more important in the marital relation, though the differences in types of love are less pronounced. These differences are likely due to the contrasting nature of the cultural relational expectations of spouse and of young-adult and parents, and of the age role differences involved in these relationships. Basic differences between marital and familial love are also probably a factor.

The two dimensions of love, benevolence and attraction, are highly correlated. This association can be interpreted as indicating integration based on both a generalized idea of the meaning of love, and its actual reality in interpersonal interaction and social relationships. For the marriage sample bivariate correlations (r) for self-reported benevolence and attraction are .60, for perceived benevolence and attraction .77. For the 
family sample, the correlations between benevolence and attraction are .67 and .78 for self-reported and perceived love, respectively, for the female parent. These figures are .73 and .77 for love for the male parent.

Factor Analysis. Whether there is a duality in the cognitive and meaningful structure of love can most appropriately be examined with factor analysis. Table 2 speaks to this question with factor solutions for both self-reported and perceived love for the married sample. A similar factor analysis for young adults and their parents is presented in Table 3 for the female parent, and Table 4 for the male parent. A varimax rotation with a criterion of 2 factors is employed to test the thesis of the meaningful duality of love.

The postulated two-dimensional structure of love is supported by the data. The results show that the items measuring the components of love are grouped into benevolence and attraction factors appropriately in all three social relationships: spousal, female parent, male parent. The KMO and Bartlett tests are satisfactory. Eigenvalues and explained variance after rotation show that both factors are strong and together explain between 62 and 75 percent of the variance. Although the separation of factors is definite, there are some instances of split-loading (over .45), mainly in results for perceived love of the male parent.

From the perspective of understanding the nature of love, the results indicate that benevolence and attraction are indeed separate but related dimensions of love in marriage and in young adult-parent relationships, with both female and male parents. The twodimensional structure of love is thus basically similar in these three relationships. A second similarity is that in all three relationships attraction explains the most variance in the case of self-reported love, while benevolence is predominant for perceived love. Perhaps individuals tend to respond to others primarily in terms of the gratification they consider they receive from the relationship, but see the love of the other more in terms of its giving and benefiting aspects.

The ranking of the components of benevolence and attraction is quite similar when data for female and male parents presented in Tables 3 and 4 are compared. In self-reported love, the emotional closeness component of attraction has the highest loading for both parental relationships, and justice, charity, and temperance are the highest loaded components for the virtues that comprise benevolence. In perceived love the ranking of the five virtues is exactly the same for both parental figures, and intimacy and admiration have the highest loadings for attraction. Table 2 shows that the ranking of the components is noticeably different in the case of the marriage sample. This most likely indicates differences in the nature of love in marriage compared to family relationships. It may also reflect the influence of factors such as age difference between subjects in the two samples, and contrasts in role and relational cultural expectations.

Specification. When the family sample is divided into male and female respondents the factor solutions definitively separate benevolence and attraction in all instances when two factors are specified as the criterion. Thus for young adults, whether male or female, the basic two-dimensional structure of both self-reported and perceived love demonstrated in the full sample is replicated. The marriage sample is too small for partialing for factor analysis.

Interpretation. In forming a perspective regarding the nature and arrangement of structures of meaning pertaining to love, the previously considered assumption of 
hierarchical integration from general to specific can interpret the findings. These empirical findings regarding the structure of love are similar to a previous and different sample that provided data regarding love between young adults and their parents [Jeffries, 1993]. This study adds to knowledge by successfully replicating the previous study, and by extending the analysis to marriage, thus indicating that love has the same basic two-dimensional structure in both marital and parental relationships.

The results also suggest that the basic schematic structure of benevolence and attraction appears to transcend age, gender, and relational schemas in shaping the structure of love. However, comparison of results between the marriage and family samples suggest that the relative importance of the components of these two basic dimensions of love appear to be influenced to some degree by either age and relational cultural expectations, or both.

\section{RESULTS: THE INTERACTIONAL DYNAMICS OF LOVE}

The previously considered Thomas Theorem provides a frame of reference for the analysis of the dynamics of love. The perceived love of the other is regarded as the definition of the situation: the independent variable. The self-reported practice of love toward the other is regarded as the consequence of this definition of the situation: the dependent variable. Although the data is cross-sectional and represents only one point in time, the findings can be interpreted as a report on ongoing interactional sequences that are generally habitual, continuous, and frequently relatively stable over time. This interaction constitutes the objective situation. Its empirical characteristics inevitably influence how the situation will by defined by the interacting parties.

Basic findings. The focus of the analysis is to investigate whether receiving love influences the manifestation of love in return. Therefore, the research question explored in the data is whether perception of receiving love from a particular person (spouse, mother, father) is positively related to self-reported love toward that person. Regression provides the most appropriate statistical test for this analysis. The stepwise multiple regression of self-reported love on perceived love is presented in Table 5 and Table 6. Explained variance (R2), its change, and its significance are reported. Partial correlations and beta weights are also presented to provide further assessment of association and of independent and relative effects.

Table 5 declares that self-reported benevolence is moderately influenced by perceived love, with R2's ranging from .31 to .45 . In the marital relationship, perceived attraction explains the most variance in self-reported benevolence. However, perceived benevolence does have independent effects. Partial correlations and beta weights also show that perceived attraction and perceived benevolence are both associated with self-reported benevolence, with attraction being relatively stronger. In the parental relationship, the dimensions of love vary in their importance. For love for female parents, the statistical results indicate that perceived attraction accounts for almost all of the variance in selfreported benevolence. In contrast, in the case of self-reported benevolence toward the male parent, perceived benevolence explains the most variance, though perceived attraction makes a significant contribution. 
Table 6 displays the regression of self-reported attraction on perceived benevolence and perceived attraction. The values of R2 range from .60 to.74. The results show the importance of perceived attraction in the manifestation of love in interaction. Perceived attraction explains the most variance in self-reported attractive love for the married and for the love of both female and male parents. In all these instances the R2 statistics, partial correlations, and beta weights also indicate the importance of perceived benevolence as an additional and generally robust independent source of attractive love. This is particularly true for the married and for benevolent love for the male parent.

Specification. The relationship between self-reported and perceived love can be further explored by dividing both samples into male and female respondents. The regression of self-reported benevolence on perceived benevolence and attraction presented in Table 5 yields two noteworthy findings when specified according to sex. Among spouses, perceived benevolence is the strongest predictor of self-reported benevolence for females (wives), though perceived attraction remains strong. For love for the male parent, perceived benevolence is the most important predictor for males (sons), though perceived attraction again remains strong.

When sex is introduced into the analysis as a specification variable, the regression of self-reported attraction on perceived benevolence and attraction shows results that are strikingly similar to those in Table 6. With one exception, attraction is the primary predictor, while benevolence is moderately strong. The exception is that among spouses, for male respondents (husbands), perceived benevolence of the spouse (wives) emerges as the strongest predictor of self-reported attraction.

Interpretation. To view the data in a broad theoretical perspective, the perception that one receives love from the other is associated with manifesting love in return. It appears that in a long-term interactional context between two persons, perceived attraction is generally the most important factor in the expression of love toward the other, particularly in the case of the expression of attractive love. Though there are exceptions in which benevolence is more important when examined among males and females separately, the predominance of attractive love generally remains. This finding is consistent with the assumption that attractive love is strongly motivated by positive interaction that fulfills needs, while benevolent love is more closely related to an internal moral commitment to benefit the other. Benevolence is thus less influenced by the perceived behavior of the other, or the nature of interaction with that other [Jeffries, 2002].

\section{DISCUSSION}

\section{Limitations}

The generalizability of the findings is to some degree restrained by the particularity of both samples. The marriage sample is not representative of the married population in general. However, the sample can be considered as representative of a specific segment of that population: middle aged or older individuals, who have been married 25 years or more, and are generally religiously active. This collective is an identifiable and important part of the cohort of married couples and of the general society. In the family sample, almost all respondents are young adults under the age of 25 . Within this segment of the 
population the sample is representative of students at general-purpose universities in ethnically heterogeneous urban areas.

A positive factor is that both samples are well suited to provide data for the variables studied. Questionnaire responses are derived from the memory of multiple, frequently occurring, and varied episodes of interaction, some involving major life events, over an extended period of years. For the married sample this interaction is ongoing, for the family sample either ongoing or recent for almost all of the respondents.

Limitations are also inherent in the nature of survey data and the corresponding statistical analysis. This research design does not provide for direct observation of the interactional processes that structure love and influence its consequences. While regression analysis provides explained variance, it does not comprehensively examine cause and effect.

\section{Theoretical Development and Future Directions}

This study has investigated a subject matter that is not well understood: the nature of love. The importance of love has been noted by Sorokin [Sorokin, 2002:486]: «universal sublime love is the supreme value around which all moral values can be integrated into one ethical system valid for the whole of humanity.» A model of the nature and components of love in interpersonal interaction and relationships has been presented. The model is derived in part from Classical Greek and Middle Age philosophy, in the writings of Aristotle and Aquinas, and is compatible with previously cited research and theories of the components of love.

Examining the previous findings and analysis of love presented in this article, three areas of investigation will be considered: the meaningful structure of love, the interactional dynamics of love, and the comparison of love in marital and in young adult-parent relationships.

Meaningful structure of love. The analysis of structure involves the identification of the components of a given phenomenon and a consideration of their arrangement. From this perspective love can be regarded a $\mathrm{s}$ a meaningful structure that resides in human consciousness and is manifested in behavior in social interaction. Marital and family relationships are the most common social contexts in which love is frequent and of long duration in social interaction.

A general model for understanding the meaningful integration of schemas with sentiments and behavior in social interaction emerges from the analysis. The foundation of the model is the assumption that some schemas, such as the love schema, are systemic in nature. This systemic nature of related schemas is created to the degree there is a common generalized meaning expressed in the various components at different levels of abstraction. This form of meaningful system is composed of multiple interrelated schemas that exist in a hierarchical relation from abstract and general to specific, with increasingly specific structures existing as substructures embedded within more general ones.

From this perspective, the meaningful structure of love entails two basic schemas that are perennially associated with ongoing sentiments in close interpersonal relationships, such as marriage and family. The duality of giving and needing forms of love is inherent in the nature of such relationships. This duality is conceptualized in this study as benevolence and attraction. Each of these dimensions of love is further specified in its components. Thus the benevolent love of giving of oneself for the welfare of another contains subschemas pertaining to more specific manifestations, defined by each of the 
primary virtues: temperance, fortitude, justice, prudence, charity. At the behavioral level of daily life and interaction, these virtue schemas provide a component of the meaningful basis for the sentiment of love for particular individuals. Attractive love is organized, specified, and expressed in a similar manner: admiration, companionship, trust, intimacy, emotional closeness. When activated, these systems of meaning can become the basis of social interaction and the formation of social relationships.

This study has systematically tested only a part of this model of the structure of love. Foremost is the statistical separation of the love schemas of benevolence and attraction into two separate factors, and the corresponding arrangement of their component parts. This model of the meaningful structure of love needs to be subjected to more precise and comprehensive investigation with differing methodologies such as intensive interviewing, observation, and experiment.

Interactional dynamics of love. The manifestations and effects of love in social interaction are the central aspect of the dynamics of love. In this regard, Sorokin [Sorokin, 2002:58] maintains that «love begets love» and «there are numerous manifestations of this uniformity.» This study has focused on a general question: whether receiving love from another leads to giving love to that person in return. In operational terms, the data analysis has focused on whether perceived benevolence and attraction are statistically associated with self- reported benevolence and attraction.

Recent research on marital and family interaction has been directed toward the identification of «transformative» variables, defined as those factors that make a positive contribution to social relationships [Fincham, Stanley, Beach, 2007]. These are regarded as variables that manifest the properties of control and of influence. They control because they create and maintain a context of meaning that can be applied by individuals in their thinking about past and future sequences of interaction in the relationship. They influence because they coordinate understandings and interaction, while also decreasing negative sequences of interaction.

The potential importance of love as a transformative variable has been suggested by a number of scholars. Bahr and Bahr [Bahr, Bahr, 2001] maintain that love that is selfsacrificing, other-centered, and giving is an important source of bonding and solidarity in family interaction. Beach, Fincham, and Stanley [Beach, Finchman, Stanley, 2007:317] emphasize the probable importance as a transformative process of unselfish love that is directed toward the benefit of the partner. Amato [Amato, 2007:306] posits that a model of positive factors in marital processes would include both romantic love with emotional bonding and the love that focuses on the other's welfare above one's own.

The results of the data analysis in this study indicate that love is a transformative process. The perception that one receives love from another is associated with giving love in return. Thus love generates love in a potentially long-term process. Attractive love generally explains more variance in self-reported love than benevolent love, though both usually have independent effects.

The predominance of attractive love as a factor in influencing the giving of love may be partially understood by considering the contrasting meaningful nature of attraction and of benevolence. Attractive love is primarily an interpersonal bond in which interaction is strongly shaped and influenced by the personal characteristics, needs, and behavior of the interacting parties. In contrast, benevolence is primarily a moral code regarding personal 
obligations and the ethical manner of relating to others. In interpersonal relationships, this moral code is applied to a particular person within the context of sentiments and conventional role expectations. The practice of benevolence is thus reinforced by cultural norms regarding the claims and obligations associated with marital and young adult-parent social relationships.

Perceiving the attractive love of the other positively influences responses of both attraction and benevolence. This finding has theoretical implications that are important. It suggests that the practice of benevolence in marriage and family relations is generally dependent on a context of attractive love to develop most fully. The bond of attractive love in interpersonal relationships appears to be an important nurturing mechanism of both benevolent and attractive love. Better understanding of the relation between these dimensions of love is an important area of further research.

Comparative analysis. The findings of this study indicate that there are similar transformative processes in both marital and young adult-parent relationships. Relationships between marital partners and between young adults and their parents generally coexist in the same family system. Therefore, providing definitive evidence regarding the existence and identity of transformative processes that are effective in family systems and throughout the kinship system would be both theoretically and practically important.

The finding that there are significant similarities in the structure and dynamics of love between spouses and between young adults and their parents indicates that love has common attributes in both relationships. These attributes appear to include basically similar meaningful structures and effects in interaction, indicating the likelihood of similar transformative processes. These commonalities suggest that the development, testing, and refinement of a general theory of the structure and dynamics of love and its effects in the interpersonal relations of marriage and of family is a promising future direction of major theoretical and practical importance. It may be the most effective path to increasing knowledge and understanding of how to improve these relationships that have such a profound effect on individual lives and thus, ultimately, on society.

Table 1. Descriptive Statistics and Paired Samples T-Tests: Comparing Attraction and Benevolence for Self-Reported and Perceived Love, for Married and Family Samples.

\begin{tabular}{cccccccc}
\multicolumn{2}{c}{ Attraction } & \multicolumn{5}{c}{ Benevolence } \\
Min-Max & Mean & SD & Min-Max & Mean & SD & T & N \\
& & & & & & & \\
& & & & & & & \\
$49-75$ & 66.65 & 6.60 & $53-75$ & 63.81 & 6.11 & $<.000$ & 102 \\
$39-75$ & 65.90 & 7.38 & $47-75$ & 65.86 & 7.62 & .938 & 103
\end{tabular}

Family Sample

Female Parent

Self-Reported

Perceived

$10-50$

37.44

8.67

$13-50$

37.52

$6.74 \quad .739$

713

$10-50$

38.29

$8.62 \quad 10-50$

41.41

$7.47<.000$

710 
Male Parent

$\begin{array}{lllllllll}\text { Self-Reported } & 10-50 & 34.87 & 9.82 & 10-50 & 37.07 & 7.88 & <.000 & 662 \\ \text { Perceived } & 10-50 & 34.57 & 9.54 & 10-50 & 38.28 & 9.21 & <.000 & 660\end{array}$

Table 2. Varimax Rotated Factor Matrixes of Scores Measuring Self-Reported and Perceived Love between Spouses, with Criteria of Two Factors.

\section{Self-Reported Love}

Factor 1: Attraction

Factor $1 \quad$ Factor $2 \quad$ h2

\section{companionship}

.79

.21

(1)

emotional closeness

.77

.34

.67

admiration

.77

.30

.71

intimacy

.76

.68

trust

.75

.24

.63

.57

Factor 2: Benevolence prudence

justice

.12

.77

.60

charity

.30

.75

.65

temperance

.25

.64

.47

fortitude

.44

.59

.54

KMO .846 Bartlett $<.000$

Eigenvalues $3.33 \quad 2.87$ \%variance $33.3 \quad 28.6 \quad 62.0$

Perceived Love

Factor 1: Benevolence

Factor 1

Factor 2

h2

fortitude

.85

.26

.79

charity

.81

.39

.81

prudence

.76

.38

.72

temperance

.71

.31

.60

justice

.67

.38

.59

Factor 2: Attraction

trust

companionship

emotional closeness

admiration

intimacy
.22

.45

.36

.38

.48
.81

.76

.76

.75

.60
.70

.78

.71

.70

.60

KMO .916 Bartlett $<.000$

Eigenvalues $\quad 3.65 \quad 3.35$ ovariance $36.5 \quad 33.5 \quad 70.0$ 
Table 3. Varimax Rotated Factor Matrixes of Scores Measuring Self-Reported and Perceived Love between Young Adults and Female Parents, with Criterion of Two Factors.

\section{Self-Reported Love}

$\begin{array}{lccc} & \text { Factor } 1 & \text { Factor } 2 & \text { h2 } \\ \text { Factor 1: Attraction } & & & .83 \\ \text { emotional closeness } & .84 & .34 & .67 \\ \text { intimacy } & .81 & .12 & .72 \\ \text { admiration } & .80 & .29 & .68 \\ \text { trust } & .78 & .26 & .77 \\ \text { companionship } & .78 & .41 & .77 \\ & & & .73 \\ \text { Factor 2: Benevolence } & & & .64 \\ \text { justice } & .24 & .84 & .69 \\ \text { charity } & .23 & .78 & .58 \\ \text { temperance } & .18 & .67 & .58 \\ \text { prudence } \\ \text { fortitude }\end{array}$

KMO .923 Bartlett $<.000$

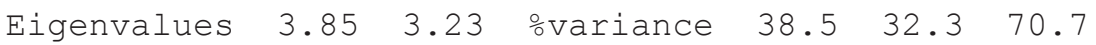

Perceived Love

Factor $1 \quad$ Factor 2 h2

Factor 1: Benevolence

justice

.84

.26

.78

fortitude

.84

.21

.74

charity

.77

.76

prudence

.76

.41

.77

temperance

.60

.44

.51

Factor 2: Attraction

intimacy

.13

.82

.68

admiration

.38

.77

.74

trust

.40

.72

companionship

.54

.75

.77

emotional closeness

.55

.69

.76

KMO .942 Bartlett $<.000$

$\begin{array}{lllllll}\text { Eigenvalues } & 3.85 & 3.38 & \text { ovariance } & 38.5 & 33.8 & 72.3\end{array}$ 
Table 4. Varimax Rotated Factor Matrixes of Scores Measuring Self-Reported and Perceived Love between Young Adults and Male Parents, with Criterion of Two Factors.

\section{Self-Reported Love}

Factor 1: Attraction

$$
\text { Factor } 1 \quad \text { Factor } 2 \quad \text { h2 }
$$

emotional closeness

.83

.81

.80

.78

.77

.27

.84

prudence

KMO .925 Bartlett $<.000$

Eigenvalues $\quad 3.94 \quad 3.73$
.83

.78

.65

.64

.54

.30

.20

.53

ovariance $\quad 39.4 \quad 33.7 \quad 73.2$

Perceived Love
Factor 1: Benevolence

justice

fortitude

charity

prudence

temperance

Factor 2: Attraction

intimacy

admiration

emotional closeness

companionship

trust

KMO .933 Bartlett $<.000$

Eigenvalues $\quad 3.86 \quad 3.67$
Factor 2

h2

Factor 1

.88

.21

.24

.46

.47

.74

.47

.65

.10

.80

.65

.41

.77

.76

.44

.77

.79

.46

.75

.78

.44

.72

.71
.82

.82

.80

.76

.64
.78

.81

.75

.63

.75

.77

.78

.65

.70

.71 
Table 5. Stepwise Multiple Regression of Self-Reported Benevolence on Perceived Benevolence and Perceived Attraction.

\begin{tabular}{|c|c|c|c|c|c|}
\hline & $\mathrm{R}^{2}$ & $\mathrm{R}^{2} \mathrm{Ch}$ & Sig & Partial & Beta \\
\hline Married Sample & & & & & \\
\hline \multicolumn{6}{|l|}{ Spouses } \\
\hline Perceived Attraction & .34 & --- & $<.000$ & .29 & .37 \\
\hline Perceived Benevolence & .37 & .03 & .030 & .22 & .28 \\
\hline
\end{tabular}

Family Sample

Female Parent

$\begin{array}{lccccc}\text { Perceived Attraction } & .308 & --- & <.000 & .36 & .50 \\ \text { Perceived Benevoolence } & .310 & .002 & .151 & .05 & .07 \\ & & & & & \\ \text { Male Parent } & & & & & \\ \text { Perceived Benevolence } & .40 & --- & <.000 & .31 & .37 \\ \text { Perceived Attraction } & .45 & .05 & <.000 & .29 & .35\end{array}$

Table 6. Stepwise Multiple Regression of Self-Reported Attraction on Perceived Benevolence and Perceived Attraction.

Married Sample

$$
R^{2} \quad R^{2} \text { Ch Sig Partial Beta }
$$

\section{Spouses}

$\begin{array}{llllll}\text { Perceived Attraction } & .66 & --- & <.000 & .51 & .47 \\ \text { Perceived Benevolence } & .74 & .08 & <.000 & .48 & .44\end{array}$

Family Sample

Female Parent

$\begin{array}{llllll}\text { Perceived Attraction } & .60 & --- & <.000 & .52 & .60 \\ \text { Perceived Benevolence } & .62 & .02 & <.000 & .22 & .23\end{array}$

Male Parent

$\begin{array}{llllll}\text { Perceived Attraction } & .69 & --- & <.000 & .58 & .56 \\ \text { Perceived Benevolence } & .74 & .05 & <.000 & .40 & .35\end{array}$




\section{References}

Amato P.R. Transformative Processes in Marriage: Some Thoughts From a Sociologist // Journal of Marriage and Family, 2007. - 69:305-309.

Aquinas T. Summa Theologica. Westminister, MD: Christian Classics, 1981.

Archer M.S. Being Human: The Problem of Agency. New York: Cambridge University Press, 2000.

Aristotle. The Basic Works of Aristotle. New York: Random House, 1941.

Bahr Howard M., Kathleen S. Bahr. Families and Self-Sacrifice: Alternative Models and Meanings for Family Theory // Social Forces, 2001. - 79(4):1231-1258.

Beach S.R., Finchman F.H., Stanley Scott M. Contextualizing the Study of Marital Transformation: Points of Convergence // Journal of Marriage and Family, 2007. - 69:315-319.

Blumer H. Symbolic Interactionism: Perspective and Method. Englewood Cliffs, NJ: Prentice Hall, 1969.

Brewer W.F., Glenn V. Nakamura. The Nature and Functions of Schemas., 1984. - Pp. 119-160 in Handbook of Social Cognition Volume 1, edited by Robert S. Wyer, Jr. and Thomas K. Srull. New Jersey: Lawrence Erlbaum Associates.

Clark M.S., Judson Mills. Interpersonal Attraction in Exchange and Communal Relationships // Journal of Personality and Social Psychology, 1979. - 37:12-24.

Collins N.L., Marie B. Ford. Responding to the Needs of Others: The Caregiving Behavioral System in Intimate Relationships // Journal of Social and Personal Relationships, 2010. - 27(2):235-244.

Coser L.A. Masters of Sociological Thought. New York: Harcort Brace Jovanovich, 1977.

Davis K.E., Michael J. Todd. Friendshp and Love Compared. Advances in Descriptive Psychology, 1982. 2:79-122.

D'Arcy M.C. The Mind and Heart of Love. New York: Meridian, 1960.

Fehr B. Prototype Analysis of the Concepts of Love and Commitment // Journal of Personality and Social Psychology, 1988. - 55:557-579.

Fehr B., Speecher S., Lynn G. Underwood. The Science of Compassionate Love. Malden, MA:WileyBlackwell, 2009.

Fincham F.D., Scott M. Stanley, S.R.H. Beach. Transformative Processes in Marriage: An Analysis of Emerging Trends // Journal of Marriage and Family, 2007. 69:275-292.

Fowers B.J. Virtue and Psychology: Pursuing Excellence in Ordinary Practices. Washington, DC: American Psychological Association, 2005.

Hendrick C., Hendrick S.S. A Theory and Method of Love // Journal of Personality and Social Psychology, 1986. - 50:392-402.

Jeffries V. Love: The Five Virtues of St. Thomas Aquinas // Sociology and Social Research, 1987. - 71: 174-182.

Jeffries V. Love as Virtue, Love as Attraction, and Relationship Quality // Family Perspective, 1988. - 22: $107-128$.

Jeffries $V$. Adolescent Love, Perception of Parental Love, and Relationship Quality // Family Perspective, 1990. - 24: 175-196.

Jeffries $V$. Virtue and Attraction: Validation of a Measure of Love // Journal of Social and Personal Relationships, 1993. - 10: 99117.

Jeffries V. Virtue and the Altruistic Personality // Sociological Perspectives, 1998. - 41: 151-166.

Jeffries $V$. The Structure and Dynamics of Love: Towards A Theory of Marital Quality and Stability // Humboldt Journal of Social Relations, 2002. - 27: 42-72.

Jeffries $V$. Religiosity, Benevolent Love, and Long Lasting Marriages // Humboldt Journal of Social Relations, 2006. - 30:77-106.

Jeffries V. Virtue Morality and Marital Solidarity (In Russian) 2014. - Pp. 109-147 in Social Solidarity and Altruism: Sociological Tradition and Modern Interdisciplinary Studies, edited by Dmitry Efremenko. Moscow: INION RAN.

Johnson M.D., Horne R.M., Franz J. Neyer. The Development of Willingness to Sacrifice and Unmitigated Communion in Intimate Partnerships // Journal of Marriage and Family, 2018. - 80: 637-652.

Levine D.L. Visions of the Sociological Tradition. Chicago: University of Chicago Press, 1995.

Lopez S.J., Snyder C.R. Positive Psychological Assessment. Washington, DC: American Psychological Association, 2003.

MacIntyre A. After Virtue. Notre Dame, IN: University of Notre Dame, 1984. 
Markus H., R.B. Zajonc. The Cognitive Perspective in Social Psychology. 1985. - Pp. 137-230 in Handbook of Social Psychology Volume 1, edited by Gardner Lindzey and Elliot Aronson. New York: Random House, Maslow, Abraham H. 1968. Toward a Psychology of Being. New York: D. Van Nostrand.

Merton R.K. Social Theory and Social Structure. New York: Free Press, 1968.

Moskowitz G.B. Social Cognition. New York: Guilford Press, 2005.

Neff L.A., Karney B.R. Compassionate Love in Early Marriage, 2009. - Pp. 201-221 in The Science of Compassionate Love, edited by Beverley Fehr, Susan Speecher, and Lynn G. Underwood. Malden, MA: Wiley-Blackwell.

Nygren A. Agape and Eros. New York: Harper and Row, 1969.

Perlman D., Aragon R.S. Compassionate Love: Concluding Reflections, 2009. - Pp. 433-452 in The Science of Compassionate Love, edited by Beverley Fehr, Susan Speecher, and Lynn G. Underwood. Malden, MA: Wiley-Blackwell.

Peterson C., Seligman Martin E.P. Character Strengths and Virtues. American Psychological Association: Oxford University Press, 2004.

Pieper J. The Four Cardinal Virtues. Notre Dame, IN: Notre Dame, 1966.

Rubin Z. Liking and Loving. New York: Holt, Rinehart \& Winston, 1973.

Shaver P., Hazan C., Bradshaw D. Love as Attachment: The Integration of Three Behavioral Systems, 1988. Pp. 68-99 in The Psychology of Love, edited by Robert J. Sternberg and Michael L. Barnes. New Haven, CT:Yale University Press.

Shibutani T. Society and Personality. Englewood Cliffs, NJ: Prentice Hall, 1961.

Singer I. The Nature of Love: Plato to Luther Volume 1. (Second Edition). Chicago: University of Chicago Press, 1984a.

Singer I. The Nature of Love: Courtly and Romantic. Volume 2. Chicago: University of Chicago Press, 1984b. Singer I. The Nature of Love: The Modern World. Volume 3. Chicago: University of Chicago Press, 1987.

Smith C. What Is a Person? Chicago: University of Chicago Press, 2010.

Sorokin P.A. Society, Culture, and Personality. New York: Cooper Square Publishers, Inc., 1969.

Sorokin P.A. Ways and Power of Love. Philadelphia: Templeton Foundation Press, 2002.

Steck L., Levitan D., McClane D., Kelley H.H. Care, Need, and Conceptions of Love // Journal of Personality and Social Psychology, 1982. - 43:481-491.

Sternberg R.J. A Triangular Theory of Love // Psychological Review, 1986. - 93:119-135.

Stryker S., Statham A. Symbolic interaction and role theory. 1985. - Pp. 311-378 In G. Lindzey \& E. Aronson (Eds.), Handbook of social psychology, Vol. I, 3rd ed. New York: Random House.

Swensen C.H. The Behavior of Love. 1972. - Pp. 86-101 in Love Today: A New Exploration, edited by Herbert A, Otto. New York: Association Press.

Swidler A. Talk of Love: How Culture Matters. Chicago: University of Chicago Press, 2001.

Tennov D. Love and Limerence: The Experience of Being in Love. New York: Stein and Day, 1984.

Thomas W.I. Situational Analysis: The Behavior Pattern and the Situation. 1966. - Pp. 154-16 in W. I. Thomas on Social Organization and Personality, edited by Morris Janowitz. Chicago: University of Chicago Press.

Thomas W.I., Thomas D.S. The Child in America: Problems and Programs. New York: Alfred A. Knopf, 1928.

Thomas W.I., Znaniecki F. The Polish Peasant in Europe and America. Volume 1. New York: Dover Publications, 1958.

Turner R.H. Role-Taking: Process Verses Conformity. 1962. - Pp. 20-40 in Human Behavior and Social Processes, edited by Arnold M. Rose. Boston: Houghton Mifflin.

Turner R.H. Family Interaction. New York: John Wiley, 1970.

Underwood L.G. Compassionate Love: A Framework for Research. 2009. - Pp. 3-25 in The S Science of Compassionate Love, edited by Beverley Fehr, Susan Speecher,and Lynn G. Underwood. Malden, MA: Wiley-Blackwell.

Zimmerman C.C. Family and Civilization. Harper \& Brothers. New Yorkand London, 1947. 